\title{
Application of zeolite-Arthrobacter viscosus system for the removal of heavy metal and dye: Chromium and Azure B
}

\author{
E. Rosales ${ }^{\text {a,* }}$, M. Pazos ${ }^{\text {a }}$, M.A. Sanromán ${ }^{\text {a }}$, T. Tavares $^{\text {b }}$ \\ a Department of Chemical Engineering University of Vigo, Isaac Newton Building, Campus As Lagoas, Marcosende 36310, Vigo, Spain

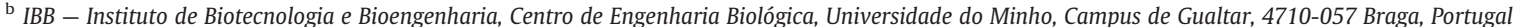

\section{A R T I C L E I N F O}

Article history:

Received 14 April 2011

Received in revised form 3 June 2011

Accepted 18 August 2011

Available online 17 September 2011

\section{Keywords:}

Adsorption isotherms

Chromium

Dye adsorption

Kinetic studies

NaY zeolite

\begin{abstract}
A B S T R A C T
A hybrid system combining the ion-exchange properties of a NaY zeolite and the characteristics of the bacterium Arthrobacter viscosus was investigated to treat polluted effluents with dye and toxic metals. In this study, the dye and the metal ion employed were a thiazine dye, Azure B, and chromium (VI), respectively. Initially, the removal of dye by the zeolite was tested. The analysis of dye equilibrium isotherms data was done using Langmuir, Freundlich, Sips and Redlich-Peterson models. Redlich-Peterson model gave the better fitting to data. In the dye adsorption studies, pseudo-second order kinetics showed the more reliable results. Operating at the optimised conditions in the treatment of single pollutants, a mixture of dye and metal solutions was treated reaching a removal higher than 50\% for chromium (VI) and higher than $99 \%$ for dye, in 8 days.
\end{abstract}

(c) 2011 Elsevier B.V. All rights reserved.

\section{Introduction}

The presence of dyes and heavy metals is usual in industrial processes like chrome tanning of tannery industry, and their removal may be an environmental problem. These industrial activities are based on chemical processes involving several organic and inorganic compounds such as: acids, chromium salts, dyes, auxiliaries and other chemical additives [1]. Dyes are widely used for colouring processes and many of them are considered hazardous. Two percent of the produced dyes are discharged directly in aqueous effluent, with a further $10 \%$ lost during the textile coloration process [2]. They are generally believed to be toxic and carcinogenic or prepared from other known carcinogens [3]. The direct discharge of dye effluents can cause serious problems to the environment due to contribution of high organic loading, toxicity and aesthetic pollution related to colour [4]. Another environmental problem is the presence of heavy metals in the effluent. Under certain environmental conditions, they may accumulate to toxic levels and cause ecological damage [5]. Amongst them, chromium is one of the major contaminants in the effluents and demands special attention as it may present several oxidation states. Between the different oxidation states, chromium (VI) is of special concern due to toxicity and potential carcinogenicity [6].

Recently, different techniques were developed and applied for the treatment of dyes and/or heavy metals in effluents. Amongst them, adsorption was shown to be an economic, simple operation and effective technique. The most commonly used adsorption agent is

\footnotetext{
* Corresponding author. Tel.: + 34986 812304; fax: + 34986812380 E-mail address: emiliorv@uvigo.es (E. Rosales).
}

activated carbon with high levels of recovery of dyes or of heavy metals. In spite of this, its use is limited by high cost and difficulty of recovery. Various low cost materials are increasingly employed as non-conventional sorbents for inorganic as well as organic substances, including synthetic dyes [7]. Nowadays, the use of clay materials is being investigated by their cost and potential for ion exchange. Zeolites possess a structural net negative charge due to isomorphic substitution of cations in the mineral lattice. They have a strong affinity for cations of transition metals, but only little affinity for anions and nonpolar organic molecules [8]. The application of a zeolite to heavy metal removal may be improved by the presence of microorganisms able to change the metal speciation. These biosorbents (zeolite and bacterium) have been previously studied to remove chromium [9-11].

The aim of this work is the treatment of an effluent which contains dyes and toxic metals such as Azure B and chromium (VI). In previous reports, the chromium removal by an adsorption process has been studied and prior to study the mixture pollutants, it is necessary to know the characteristics of the adsorption process behaviour when the effluent contains a dye as pollutant. Therefore, in this work a sequential study has been proposed. Initially, the adsorption process of Azure B dye in NaY zeolite has been studied. Furthermore, a lowcost system combining the biotransformation properties of a microorganism with the ion-exchange properties of a zeolite has been developed to remove simultaneously the chromium and dye from the effluent. This innovative process combines the reduction of chromium (VI) to chromium (III) by the bacterium Arthrobacter viscosus with adsorption of the dye and chromium in a NaY zeolite. In our knowledge, few studies were done with Azure B and the treatment with zeolite of a mixture of dye and chromium. 


\section{Material and methods}

\subsection{Materials and reagents}

Dye solutions were prepared with Azure B purchased from Aldrich (CAS Number 531-55-5). Its structure and properties are shown in Table 1. Aqueous solutions were prepared according to the experiments in concentrations between 1.5 and $2500 \mathrm{mg} / \mathrm{L}$.

Chromium solutions were prepared by diluting $\mathrm{K}_{2} \mathrm{Cr}_{2} \mathrm{O}_{7}$ (Riedel-de Haen) in distilled water.

NaY zeolite (relationship Si/Al 2.83, BET area $700 \mathrm{~m}^{2} / \mathrm{g}$ ) was used as support. Prior to use, the faujasite zeolite $\mathrm{NaY}$ (Zeolyst International) was pre-treated by calcination at $500{ }^{\circ} \mathrm{C}$ during $8 \mathrm{~h}$ under a dry air stream.

A. viscosus was obtained from the Spanish Type Culture Collection of the University of Valencia.

\subsection{Methodology}

\subsubsection{Dye batch adsorption}

Erlenmeyer flasks $(250 \mathrm{~mL}$ ) containing $1 \mathrm{~g}$ of NaY zeolite in $150 \mathrm{~mL}$ of different Azure B solutions were employed. Isotherm studies were made with concentration solutions of Azure B between 1.5 and $2500 \mathrm{mg} / \mathrm{L}$. Kinetic studies were made at a concentration of $10 \mathrm{mg} / \mathrm{L}$ for 15 min.

To study the effect of $\mathrm{pH}$ on dye removal, $\mathrm{pH}$ values range from 2 to 7.5. The solution $\mathrm{pH}$ was regularly maintained at the desired value using $\mathrm{H}_{2} \mathrm{SO}_{4}$ or $\mathrm{NaOH}(0.1 \mathrm{M})$ solutions.

All the experiments were performed in a rotary shaker at $150 \mathrm{rpm}$ and $28{ }^{\circ} \mathrm{C}$.

\subsubsection{Batch adsorption}

A. viscosus biofilm formation was prepared according to Quintelas and Tavares [12-14]. A medium with $10 \mathrm{~g} / \mathrm{L}$ of glucose, $5 \mathrm{~g} / \mathrm{L}$ of peptone, $3 \mathrm{~g} / \mathrm{L}$ of malt extract and $3 \mathrm{~g} / \mathrm{L}$ of yeast extract was used for growth and maintenance of the microorganism. Bacterium was harvested during the exponential phase of the growth curve. The experiments were performed with $250 \mathrm{~mL}$ Erlenmeyer flasks containing $1 \mathrm{~g}$ of $\mathrm{NaY}$ zeolite covered with biofilm (bacterium concentration $5 \mathrm{~g} / \mathrm{L}$ ) and $150 \mathrm{~mL}$ of the different solutions mixture of dye and chromium at concentrations: $100 \mathrm{mg} / \mathrm{L}$ chromium with 100, 150, 300, 450, $600 \mathrm{mg}$ / $\mathrm{L}$ of dye. All adsorption experiments were performed in a rotary shaker at $150 \mathrm{rpm}$, temperature $28^{\circ} \mathrm{C}$.

Samples of $1 \mathrm{~mL}$ were taken, centrifuged and analysed for dye and chromium determination. These experiments were performed twice, being the experimental error margin below $3 \%$.

\subsection{Analytical methods}

\subsubsection{Azure B determination}

The dye content was measured spectrophotometrically (T60 UV Visible, PG Instruments) in the supernatant based on the constructed calibration curves at maximum absorption wavelength (648 nm). The sample was diluted with distilled water if the absorbance exceeded the range of calibration curve.

\subsubsection{Chromium determination}

Hexavalent chromium was quantified by measuring absorbance at $540 \mathrm{~nm}$ of the purple complex of chromium (VI) with 1,5-diphenylcarbazide [15] in acidic solution (T60 UV Visible, PG Instruments). For total chromium determination, the chromium (III) was first oxidised to chromium (VI) at high temperature by the addition of an excess of potassium permanganate previous to the reaction with 1,5-diphenylcarbazide. The chromium (III) concentration was calculated by the difference between the total chromium and chromium (VI) concentration.

2.3.3. Azure B and chromium adsorption uptake and removal percentages

The amount of dye or chromium adsorbed and the percentages of removal were calculated using the following equations:

$q=\left(C_{i}-C_{f}\right) \cdot V / M$

$D=100 \cdot\left(C_{i}-C_{f}\right) / C_{i}$

where $q$ is the dye uptake $(\mathrm{mg} / \mathrm{g}) ; C_{i}$ and $C_{f}$ the initial concentration and the concentration through time in the solution $(\mathrm{mg} / \mathrm{L})$ respectively; $V$ is the solution volume $(\mathrm{L}) ; M$ is the mass of adsorbent $(\mathrm{g}$ ) and $\mathrm{D}$ the percentage of dye or chromium removal (\%).

\section{Results and discussion}

Zeolites are crystalline aluminosilicates mineral consisting of a framework of tetrahedral molecules, linked with shared oxygen atoms. Zeolites usually have a large surface area and high cation exchange capacity (CEC), and provide an exchange complex that can retain different size ions, which promotes their use as selective adsorbent for oil and gas pollutants, pesticides, and metals [14]. The chromium (VI) removal ability of some zeolites is known, however in our knowledge there are no similar studies for dye remediation for the mixture of both pollutants. Therefore, it is necessary to evaluate the dye adsorption process prior to study the remediation of pollutant mixtures. For this reason, several variables such as solution $\mathrm{pH}$, dye concentration and kinetic behaviour must be studied.

\subsection{Azure B adsorption}

\subsubsection{Effect of $p H$}

Initially the effect of the solution pH on the Azure B adsorption capacity of the NaY zeolite was studied. The work was done at the $\mathrm{pH}$ values of 2, 4, 6 and 7.5 in order to obtain adsorption equilibrium data (Fig. 1).

Initially, adsorption showed a linear rising with instantaneous uptake followed by a stationary state. In all cases, the dye uptake profiles were high with values from 1.30 to $1.42 \mathrm{mg}_{\text {dye }} / \mathrm{g}_{\text {zeolite }}$. The best results, obtained at $\mathrm{pH} 4$, may be related to the surface charge density decreasing with an increase in the solution $\mathrm{pH}$ and then the electrostatic repulsion between the positively charged dye and the surface

Table 1

Azure B properties and structure.

\begin{tabular}{|c|c|c|c|c|c|}
\hline Dye & Type & C.I. & Structure & $\begin{array}{l}\lambda_{\max } \\
(\mathrm{nm})\end{array}$ & $\begin{array}{l}\text { Concentration } \\
(\mathrm{mg} / \mathrm{L})\end{array}$ \\
\hline Azure B & Cationic metachromatic thiazine dye & 52010 & & 648 & $1.5-2500$ \\
\hline
\end{tabular}




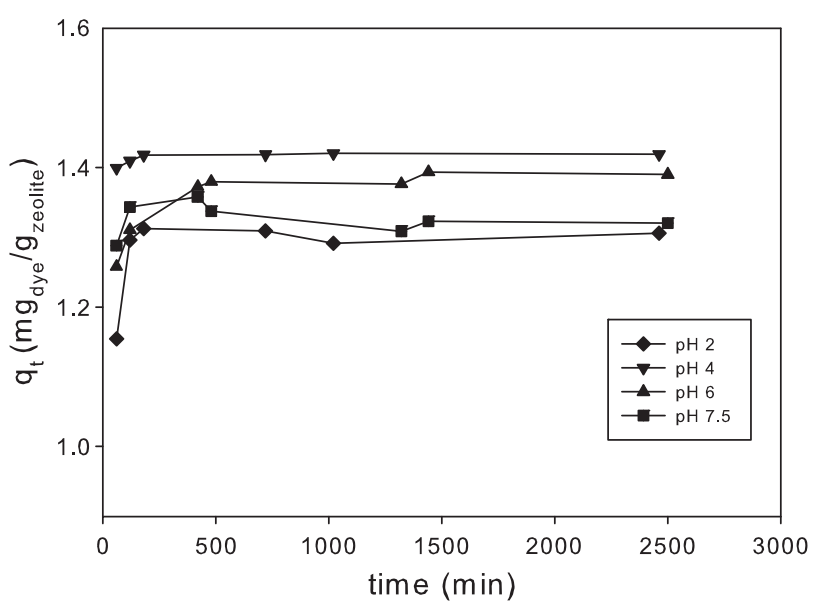

Fig. 1. Effect of pH on adsorption of Azure B into NaY zeolite (adsorbent dosage $1 \mathrm{~g}$, initial dye concentration $10 \mathrm{mg} / \mathrm{L}$ ).

of adsorbents is lowered, which may result in an increase in the extent of adsorption [16]. The low uptake value obtained at $\mathrm{pH} 6$ and 7.5 can be explained by a greater concentration of the $\mathrm{OH}^{-}$in the system which makes a competitive reaction with the zeolite. On the other hand, the lower level of adsorption reached at $\mathrm{pH} 2$ can be due to the concentration of $\mathrm{H}^{+}$ions that interact with the zeolite reducing the adsorption active sites, as Qiu et al. suggested [16].

\subsubsection{Effect of Azure B concentration}

The effect of the Azure B concentration on NaY zeolite adsorption was investigated under the equilibrium conditions. Dye concentration ranged from 10 up to $2500 \mathrm{mg} / \mathrm{L}$ was selected to investigate the removal efficiency (Table 2 ).

As shown in Table 2, when the dye concentration employed was amongst $10-120 \mathrm{mg} / \mathrm{L}$ the dye removal percentages were nearly constant (98.26-99.33\%). The maximum removal percentage was $99.33 \%$ obtained with $60 \mathrm{mg} / \mathrm{L}$ of Azure B. For higher concentrations the dye removal decreased significantly. A similar effect was detected by Qiu et al. [16] when studied the adsorption of Amino Black 108 and Sagranine T. An explanation of this fact could be the limitation of adsorption sites on the zeolite surface [4]. On the other hand, the uptake capacity increased gradually with the concentration of the dye. The maximum adsorption capacity attained was $140.953 \mathrm{mg} / \mathrm{g}_{\text {zeolite }}$ at an Azure B initial concentration of $2500 \mathrm{mg} / \mathrm{L}$. In accordance with these results, Vimonses et al. [17] and Yao et al. [18] suggested that an increase in the initial dye concentration leads to an increase in mass gradient between the solution and adsorbent and this acts as a driving force for the transfer of dye molecules from bulk solution to the particle surface. The result obtained is more than twice higher than other found in literature with other thiazine dye such as methylene blue [19].

\section{Table 2}

Comparison of equilibrium uptakes and adsorption yields obtained at different initial Azure $\mathrm{B}$ dye concentrations into $\mathrm{NaY}$ zeolite (adsorbent dosage $1 \mathrm{~g}, \mathrm{pH}=4$, agitation $\left.150 \mathrm{rpm}, \mathrm{V}=150 \mathrm{~mL}, \mathrm{~T} 28^{\circ} \mathrm{C}\right)$.

\begin{tabular}{lcc}
\hline $\mathrm{C}_{\mathrm{i}}\left(\mathrm{mg}_{\text {dye }} / \mathrm{L}\right)$ & $\mathrm{q}_{\mathrm{e}}\left(\mathrm{mg}_{\text {dye }} / \mathrm{g}_{\text {zeolite }}\right)$ & $\mathrm{D}(\%)$ \\
\hline 10 & 1.469 & 98.26 \\
30 & 4.751 & 98.91 \\
60 & 9.460 & 99.33 \\
90 & 13.297 & 99.15 \\
120 & 18.257 & 98.86 \\
500 & 58.727 & 78.22 \\
700 & 73.517 & 78.24 \\
1800 & 125.885 & 45.19 \\
2500 & 140.953 & 37.89 \\
\hline
\end{tabular}

\subsubsection{Azure B adsorption isotherm}

In order to optimise the design of an adsorption system to remove pollutants from effluent, it was required to establish the most appropriate correlation of equilibrium curves, commonly known as adsorption isotherms. The adsorption isotherms are important in describing how the adsorbate molecules are distributed between the liquid and the solid phases when the adsorption process reaches an equilibrium state. Interactions between adsorbate molecules and adsorbent surface were investigated using several well-known models of two and three fitting parameters. The models of Langmuir, Freundlich, Sips and Redlich-Peterson were chosen.

\subsubsection{Two-parameter models}

3.1.3.1.1. Langmuir isotherm. The Langmuir isotherm is based on the assumption of a structurally homogeneous adsorbent, a monolayer coverage and all the surface points are equal. Once a dye molecule occupies a site, no further adsorption can take place at that site. The equation is given as:

$q=q_{\max } \cdot b_{L} \cdot C_{f} /\left(1+b_{L} \cdot C_{f}\right)$

where $q_{\max }\left(\mathrm{mg}_{\text {dye }} / \mathrm{g}_{\text {zeolite }}\right)$ corresponds to the maximum achievable uptake by a system, and $b_{L}\left(\mathrm{~L} / \mathrm{mg}_{\text {dye }}\right)$, which is related to the affinity between the adsorbate and adsorbent. The Langmuir constant $q_{\max }$ is often used to compare the performance of adsorbents, whilst the other constant $b_{L}$ characterises the initial slope of the isotherm. Thus, for a good adsorbent, a high $q_{\max }$ and a steep initial isotherm slope (i.e., high $b_{L}$ ) are generally desirable [20].

According to Weber and Chakraborty [21], the favourable adsorption of Langmuir isotherm can be expressed in terms of a dimensionless constant separation factor or equilibrium parameter $R_{L}$.

$\mathrm{R}_{\mathrm{L}}=1 /\left(1+b_{\mathrm{L}} \cdot C_{0}\right)$

where $b_{L}$ is the Langmuir constant and $C_{0}$ is the initial concentration of dye. The value of separation factor $R_{L}$ provides valuable information about the nature adsorption. The value of $R_{L}$ indicated the type of isotherm to be irreversible $\left(R_{L}=0\right)$, favourable $\left(0<R_{L}<1\right)$, linear $\left(R_{L}=1\right)$ or unfavourable $\left(R_{L}>1\right)$.

3.1.3.1.2. Freundlich isotherm. The Freundlich isotherm was originally empirical in nature, but was later interpreted as the adsorption on heterogeneous surfaces or surfaces supporting sites with various affinities. It is assumed that the stronger binding sites are initially occupied, with the binding strength decreasing with increasing degree of site occupation. The Freundlich isotherm can be represented as:

$q_{F}=K_{F} \cdot C^{1 / n_{F}}$

It incorporates two constants: $K_{F}\left(\mathrm{mg}_{\text {dye }}^{1-1 / n_{F}} \cdot \mathrm{L}^{1 / n_{F}} / \mathrm{g}_{\text {zeolite }}\right)$, which corresponds to the binding capacity; and $n_{F}$, which characterise the affinity between the sorbent and sorbate.

The magnitude of the exponent $1 / n_{F}$ gives an indication of the favourability of adsorption. It is generally stated that values of $n_{F}$ in the range 2-10 represent good adsorption, 1-2 moderately difficult adsorption and less than 1 poor adsorption characteristics.

3.1.3.1.3. Three-parameter models. Despite the simplicity of these two-parameter models, some three-parameter models have also been widely used and tested. Amongst them, Redlich-Peterson and Sips isotherms are the most successful three-parameter models used $[22,23]$. Both models reflected the combined feature of Langmuir and Freundlich isotherm models.

3.1.3.1.4. Redlich-Peterson isotherm. Redlich-Peterson model [24] includes an exponent $\left(\beta_{R P}\right)$, which lies between 0 and 1 . There are two 
limiting behaviours: the Langmuir form for $\beta_{R P}=1$ and Freundlich form for $\beta_{R P}=0$.

$q=K_{R P} \cdot C_{f} /\left(1+a_{R P} \cdot C_{f}^{\beta_{R P}}\right)$

where $K_{R P}\left(\mathrm{~L} / \mathrm{g}_{\text {zeolite }}\right)$ and $a_{R P}\left(\mathrm{~L}^{\beta} / \mathrm{mg}_{\text {dye }}^{\beta}\right)$ are the Redlich-Peterson model constants, $\beta_{R P}$ is the Redlich-Peterson model exponent.

3.1.3.1.5. Sips isotherm. Under low sorbate concentrations, Sips model [25] effectively reduces to Freundlich isotherm and; thus, does not obey Henry's law. For high sorbate concentrations, it predicts a monolayer adsorption capacity, characteristic of the Langmuir isotherm.

$q=K_{S} \cdot C_{f}^{\beta_{S}} /\left(1+a_{S} \cdot C_{f}^{\beta_{S}}\right)$

where $K_{S}\left(\mathrm{~L}^{\beta s} \cdot \mathrm{mg}_{\text {dye }}^{1-\beta s} / \mathrm{g}_{\text {zeolite }}\right)$ and $a_{S}\left(\mathrm{~L}^{\beta s} / \mathrm{mg}_{\text {dye }}^{\beta s}\right)$ are the Sips model constant; $\beta_{S}$ the Sips model exponent which lies between 0 and 1. There are two limiting behaviours: the Langmuir form for $\beta_{S}=1$ and Freundlich form for $\beta_{S}=0$.

The fit of the analysed models to the data along with the isotherm constants and correlation coefficients $\left(\mathrm{R}^{2}\right)$ for the four models are presented in Fig. 2.

The results of the present study indicated that the Langmuir model did not fit the experimental data due to low $R^{2}$ value which suggested that homogeneous and monolayer mode of adsorption was not suitable in the present case. The obtained value of $b_{L}$ was low, which it is not very desirable according to Kratochvil and Volesky [20]. The $R_{L}$ value was found to be 0.953 to 0.075 for concentration of $10-2500 \mathrm{mg} / \mathrm{L}$ of dye indicating that the type of isotherm is
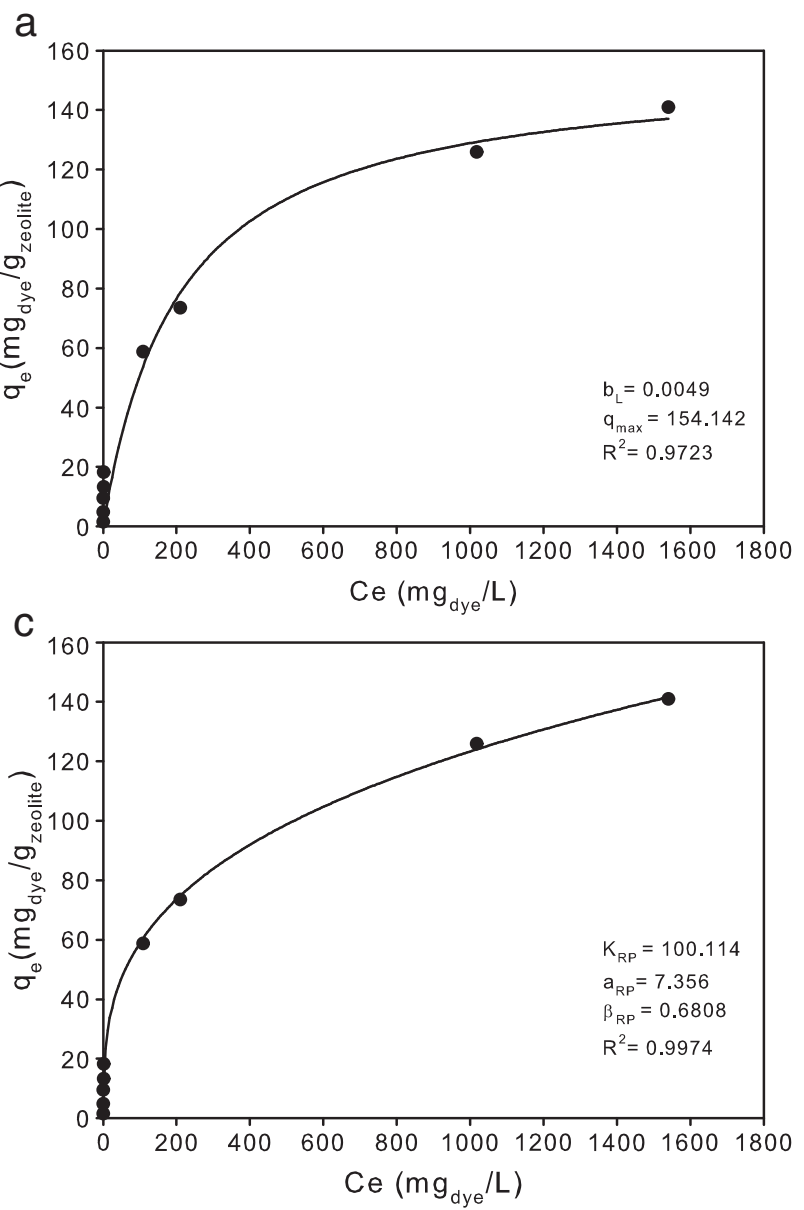

favourable. In addition, the $q_{\max }$ calculated with this model is greater than reported to similar dyes as methylene blue [19].

The Freundlich model exhibited good fit to the experimental sorption data suggesting the heterogeneous mode of adsorption since $\mathrm{R}^{2}$ value was 0.9968 . Furthermore, the $\mathrm{n}_{\mathrm{F}}$ value, which is related to the distribution of bonded ions on the adsorbent surface, was found to be 3.011 indicating that adsorption of dye onto NaY zeolite is favoured [26-28]. A suitable explanation for the adsorption mechanism would be that the stronger binding sites were initially occupied, with the binding strength decreasing with increasing degree of site occupation.

The abilities of the three-parameter models, Redlich-Peterson and Sips, were examined to model the equilibrium data. In terms of $\mathrm{R}^{2}$ values, the three-parameter models were better than the two-parameter models as expected from the number of parameters involved in the models. Thus, the three-parameter models suggested a non-monolayer sorption. The best representation of the experimental results of the adsorption isotherms was obtained using the Redlich-Peterson model $\left(R^{2}=0.9974\right)$. The $\beta_{R P}$ value $(0.6808)$ indicates that the adsorption system was between the two limiting behaviours.

\subsubsection{Azure B adsorption kinetics}

In order to develop applications of the system, operation control and adsorption kinetic are very important to the process design. They provide us valuable insights into the reaction pathways and mechanism of the reaction.

3.1.4.1. Pseudo-first-order model. Pseudo-first-order equation or Langergren's kinetic equation [29] have often been used to describe the adsorption of an adsorbate from an aqueous solution. This
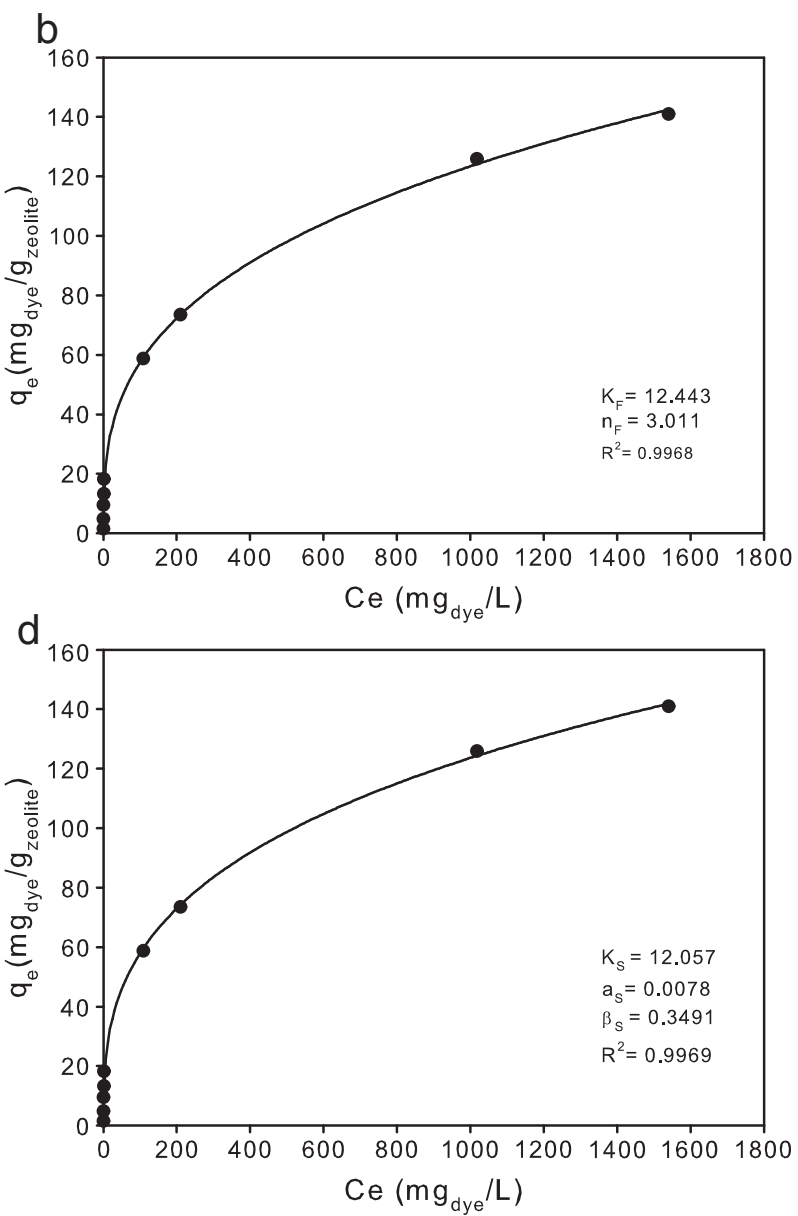

Fig. 2. Langmuir (a), Freundlich (b), Redlich-Peterson (c) and Sips (d) isotherms for Azure B adsorption onto NaY zeolite. 
kinetic equation is based on the assumption that the rate of change of solute uptake with time is directly proportional to the difference in saturation concentration and the amount of adsorbate uptake with time.

$d q / d t=k_{1} \cdot\left(q_{e}-q_{t}\right)$

when $q_{t}=0$ at $t=0$, the expression can be integrated into the following equation:

$q_{t}=q_{e} \cdot\left(1-\exp \left(-k_{1} \cdot t\right)\right)$

where $q_{t}$ is the amount of solute sorbed at time $t\left(\mathrm{mg}_{\text {dye }} / \mathrm{g}_{\text {zeolite }}\right) ; q_{e}$ is the amount of solute sorbed at equilibrium $\left(\mathrm{mg}_{\text {dye }} / \mathrm{g}_{\text {zeolite }}\right)$ and $k_{1}$ the first-order equilibrium rate constant $(1 / \mathrm{min})$.

3.1.4.2. Pseudo-second-order model. The pseudo-second-order kinetics, described by Ho \& McKay [27], is:

$d q / d t=k_{2} \cdot\left(q_{e}-q_{t}\right)^{2}$

Integrating Eq. (9) and noting that $q_{t}=0$ at $t=0$, the equation can be rearranged into:

$q_{t}=q_{e}-q_{e} /\left(1+q_{e} \cdot k_{2} \cdot t\right)$

where $q_{t}$ is the amount of solute sorbed at time $t\left(\mathrm{mg}_{\text {dye }} / \mathrm{g}_{\text {zeolite }}\right), q_{e}$ is the amount of solute sorbed at equilibrium $\left(\mathrm{mg}_{\text {dye }} / \mathrm{g}_{\text {zeolite }}\right)$ and $k_{2}$ the second-order equilibrium rate constant $\left(\mathrm{g}_{\text {zeolite }} /\left(\mathrm{mg}_{\text {dye }} \cdot \mathrm{min}\right)\right)$.

The pseudo-second-order model equation provides an excellent fit between the predicted curves and the experimental values, whereas the first-order kinetics did not fit well to the experimental data. This fact was confirmed by a good linearization of the data with $\mathrm{R}^{2}>0.999$ (Fig. 3). Pseudo-second-order adsorption rate constant $\left(k_{2}\right)$ and equilibrium uptake values $\left(q_{e}\right)$ were determined from the slope and the intercepts of the plots in the linearized form of the pseudo-second-order model (Eq. 8). The calculated $q_{\mathrm{e}}$ values also agree very well with the experimental data $\left(q_{e}=1.4182 \mathrm{mg}\right.$ dye $\left./ \mathrm{g}_{\text {zeolite }}\right)$. The best fit of the second-order expression suggests that the chemisorption mechanism is involved in the adsorption. Similar phenomena were observed for some thiozine dyes adsorption like methylene blue.

\subsubsection{Azure $B$ adsorption mechanism}

Intraparticle diffusion has often been shown to be an important factor in the attainment of equilibrium and in the identification of the adsorption mechanism for design purposes. The kinetic results were analysed by the diffusion model because neither pseudo-first-

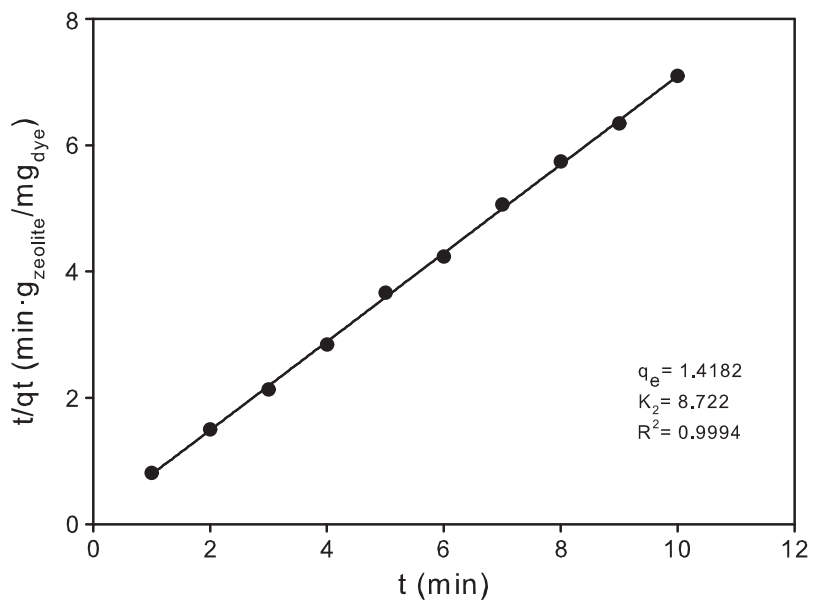

Fig. 3. Pseudo-second-order kinetics for adsorption of Azure B on NaY zeolite (adsorbent dosage $1 \mathrm{~g}$, initial Azure B concentration $10 \mathrm{mg} / \mathrm{L}, \mathrm{pH}=4$ ). order nor pseudo-second-order model can identify the diffusion mechanism.

The effect of intraparticle diffusion resistance on adsorption can be determined fitting an intraparticle diffusion plot to the kinetic data [30]:

$q_{t}=k_{i d} \cdot t^{1 / 2}+I$

where $k_{i d}$ is the intra-particle diffusion rate constant $\left(\mathrm{mg}_{\text {dye }} /\left(\mathrm{g}_{\text {zeolite }}\right.\right.$. $\left.\min ^{2}\right)$ ). Values of I give information regarding the thickness of boundary layer, i.e. the larger intercept the greater is the boundary layer effect.

The regression are not linear over the whole time range but can be divided in a few linear regions. According to Vimonses et al. [17] this may indicate the existence of several adsorption stages taking place because some resistance to mass transfer may be involved during the adsorption. The fact that none of the lines pass through the origin, $I \neq 0$, indicates that the intraparticle diffusion is not the only rate-controlling step involved in the adsorption process. Lorenc-Grabowska and Gryglewizc [31] explained such multilinearity stages. The first section may be attributed to the diffusion of adsorbate through the solution to the external surface of adsorbent or the boundary layer diffusion of solute molecules. The second portion describes the gradual adsorption stage, where intraparticle diffusion rate is rate-limiting. The third portion refers to the final equilibrium stage for which the intraparticle diffusion starts to slow down due to the extremely low adsorbate concentration left in the solution.

\subsubsection{Effect of $A$. viscosus biofilm}

Based on Silva et al. [11] and Figueiredo et al. [32] the presence of bacterium $A$. viscosus improves the chromium removal. Previous tests were done to evaluate the effect of the biomass in the dye adsorption conditions. It is concluded that the A. viscosus biofilm did not modify the obtained adsorption profiles of Azure B and the dye adsorption mainly takes place on $\mathrm{NaY}$ zeolite surface.

\subsection{Model effluent treatment}

In this study, the ability to Azure B adsorption of a zeolite was determined and in previous papers [11,32] a reduction of chromium (VI) to chromium (III) by the bacterium A. viscosus with adsorption of chromium (III) in a zeolite was proved. Therefore, the adsorbent obtained by combination of $\mathrm{NaY}$ zeolite and $A$. viscosus has been tested in order to degrade an effluent like chrome tanning of tannery industry.

Operational conditions were established according to the results previously obtained in the dye adsorption studies and described in bibliography [11,32]. Experimental studies were done in $150 \mathrm{~mL}$ at $\mathrm{pH} 4$, using $1 \mathrm{~g}$ $\mathrm{NaY}$ zeolite, $5 \mathrm{~g} / \mathrm{L}$ of biomass, agitation $150 \mathrm{rpm}$ and $28^{\circ} \mathrm{C}$. Different dye concentrations $(60,150,300,450$ and $600 \mathrm{mg} / \mathrm{L})$ were tested with a chromium concentration of $100 \mathrm{mg} / \mathrm{L}$. The obtained data are shown in Table 3.

In all cases, the dye was the first pollutant to be removed with a level higher than $99 \%$ after one hour. The chromium exhibits two adsorption stages typical of adsorption kinetics: first associated with external cell surface reaching a removal of approximately $40 \%$ in one

Table 3

Adsorption uptake values into NaY zeolite for a mixture of Azure B and chromium (VI) at different initial dye concentrations (adsorbent dosage $1 \mathrm{~g}, \mathrm{pH}=4$, agitation $150 \mathrm{rpm}$, $\left.\mathrm{V}=150 \mathrm{~mL}, \mathrm{~T} 28^{\circ} \mathrm{C}\right)$.

\begin{tabular}{lrll}
\hline \multicolumn{2}{l}{ Initial concentration $\left(\mathrm{mg}_{\text {dye }} / \mathrm{L}\right)$} & $\mathrm{D}(\%)$ & $\begin{array}{l}\mathrm{Cr}(\mathrm{VI}) \\
\text { removal }(\%)\end{array}$ \\
\hline Chromium & Dye & & 47.68 \\
100 & 60 & 99.28 & 69.60 \\
100 & 150 & 99.25 & 59.81 \\
100 & 300 & 99.54 & 60.59 \\
100 & 450 & 99.48 & 61.44 \\
100 & 600 & 99.82 & \\
\hline
\end{tabular}




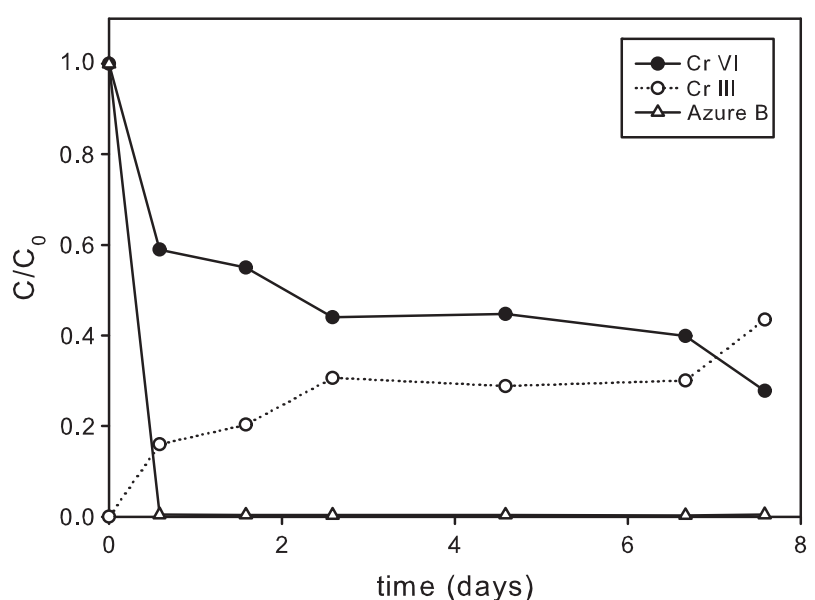

Fig. 4. Normalised concentration $\left(C / C_{0}\right)$ plot of Azure $B$ and chromium adsorption in presence of $A$. viscosus into $\mathrm{NaY}$ zeolite at $300 \mathrm{mg} / \mathrm{L}$ and $100 \mathrm{mg} / \mathrm{L}$ initial concentration respectively ( $\mathrm{pH}=4$, adsorbent dosage $1 \mathrm{~g}$ ).

day, followed by intracellular accumulation/reaction. Fig. 4 shows the typical adsorption profile obtained. Accordingly the NaY zeolite showed preference for the adsorption of the dye and later the adsorption of the chromium in the zeolite. This may be explain by the affinity between the positive charge of the dye and the negative charge in the zeolite due to the negative charge of the framework Al atoms, which are located inside the three-dimensional pore structure of the solid $[10,11,33]$. The predominant species of chromium (VI) at $\mathrm{pH} 4$ are $\mathrm{CrO}_{4}^{-2}$ (1\%) and $\mathrm{HCrO}_{4}^{-}$(99\%). The presence of chromium (VI) in an aqueous media as an anion with a big radius implies repulsion forces and a size that difficult the adsorption into the zeolite which is related with its anionic form. Figueiredo et al. [32], who studied adsorption of chromium in NaY zeolite, reported a chromium uptake two-fold higher than our system. This fact suggested a competitive behaviour between chromium and the dye, thus the dye presence reduced the available active sites.

After $100 \mathrm{~h}$, the total chromium removal was constant. The chromium (VI) was slowly reduced to chromium (III) as shown in the Fig. 4, being this ion easily exchanged in the internal surface of the zeolite. The chromium removal was favoured by the presence of $A$. viscosus which is suggested to reduce the chromium (VI) to its oxidation state chromium (III) by chromate reductase activity [34-37], thus it is more easily sorbed in zeolite [11]. However, a level was reached at which the zeolite does not accept the uptake of more chromium. In spite of this, values higher than $50 \%$ of chromium (VI) removal were reached in all the experiments. This may be due to the change of the oxidation state of chromium from VI to III in presence of the bacterium. This change may be useful because this lower oxidation state is less harmful to the environmental. The toxicity of chromium (III) is 1000 -fold lower than chromium (VI). When a dye concentration of $150 \mathrm{mg} / \mathrm{L}$ and chromium concentration of $100 \mathrm{mg} / \mathrm{L}$ were tested, removal values of $70 \%$ of chromium (VI) and more than 99\% of Azure B were reached in 8 days.

After this adsorption treatment, exhausted $\mathrm{NaY}$ zeolite (containing dye and chromium) is generated and it could be recovered by thermal treatment. The heat generated during calcination decomposed the organic contaminants on the surface or pores of the adsorbent and then oxidised to carbon oxides in air [38]. Then, the NaY zeolite with chromium could be used to catalytic purposes [10].

\section{Conclusions}

The results obtained in this work demonstrated that Azure B can be effectively removed by adsorption in $\mathrm{NaY}$ zeolite. Adsorption isotherms of Azure B on the zeolite were studied using Langmuir, Freundlich, Sips and Redlich-Peterson isotherm models. Amongst all the tested isotherm models for the description of adsorption equilibrium isotherms of Azure $B$ on zeolite, the best fitting model was Redlich-Peterson. Kinetic studies on sorption of Azure B on zeolite system revealed that pseudo-secondorder model showed the best fit to the experimental data suggesting that a chemisorption mechanism is involved in the adsorption.

This innovative process showed that zeolite-biomass system is able to perform the removal of a combination of Azure B and chromium reaching a removal levels higher than $50 \%$ in case of chromium (VI) and more than $99 \%$ for Azure B. The presence of the bacterium facilitates the reduction of the chromium (VI), the consequent adsorption to the $\mathrm{NaY}$ zeolite and reduction of the toxicity of the effluent.

The aforementioned results show that the hybrid system developed in this work is a strong choice for recovery operations as it is operationally very simple and can adapt to different dye and metal compositions. The system appears to be a promising process to the removal of both pollutants simultaneously (inorganic and organic pollutants) reducing the pollutant charge and toxicity.

\section{Nomenclature}

$q_{\max } \quad$ Langmuir model maximum achievable uptake by a system $\left(\mathrm{mg}_{\text {dye }} / \mathrm{g}_{\text {zeolite }}\right)$

$b_{L} \quad$ Langmuir model affinity between the sorbate and sorbent $(\mathrm{L} / \mathrm{mg})$

$R^{2} \quad$ Coefficient of determination

$K_{F} \quad$ Freundlich model binding capacity $\left(\operatorname{mg}_{\text {dye }}^{1-1 / n_{\mathrm{F}}} \cdot \mathrm{L}^{1 / \mathrm{n}_{\mathrm{F}}} / \mathrm{g}\right)$

$n_{F} \quad$ Freundlich model affinity between the sorbent and sorbate

$K_{R P} \quad$ Redlich-Peterson model isotherm constant ( $\left.\mathrm{L} / \mathrm{g}_{\text {zeolite }}\right)$

$a_{R P} \quad$ Redlich-Peterson model constant $\left(\mathrm{L}^{\beta} / \mathrm{mg}_{\text {dye }}^{\beta}\right)$

$\beta_{R P} \quad$ Redlich-Peterson model exponent

$K_{S} \quad$ Sips model isotherm constant $\left(\mathrm{L}^{\beta s} \cdot \mathrm{mg}_{\text {dye }}^{1-\beta s} / \mathrm{g}_{\text {zeolite }}\right)$

$a_{s} \quad$ Sips model constant $\left(\mathrm{L}^{\beta s} / \mathrm{mg}_{\text {zeolite }}^{\beta s}\right)$

$\beta_{S} \quad$ Sips model exponent

$k_{1} \quad$ Pseudo-first-order rate constant $(1 / \mathrm{min})$

$k_{2} \quad$ Pseudo-second-order rate constant $\left(\mathrm{g}_{\text {zeolite }} /\left(\mathrm{mg}_{\text {dye }} \cdot \mathrm{min}\right)\right)$

$C_{e} \quad$ Concentration of dye solution at adsorption equilibrium $\left(\mathrm{mg}_{\text {dye }} / \mathrm{L}\right)$

$C_{i} \quad$ Initial dye concentration of dye solution $\left(\mathrm{mg}_{\text {dye }} / \mathrm{L}\right)$

$q_{e} \quad$ Equilibrium adsorption capacity of adsorbent $\left(\mathrm{mg}_{\text {dye }} / \mathrm{g}_{\text {zeolite }}\right)$

$q_{t} \quad$ Amount of dye adsorbed per unit of adsorbent at time $\mathrm{t}$ ( $\left.\mathrm{mg}_{\text {dye }} / \mathrm{g}_{\text {zeolite }}\right)$

$t \quad$ Contact time (min)

$k_{\text {id }} \quad$ Intra-particle diffusion rate constant $\left(\mathrm{mg} /\left(\mathrm{g} \cdot \mathrm{min}^{1 / 2}\right)\right)$

\section{Acknowledgements}

This work was supported by Fundação para a Ciência e Tecnologia (FCT-Portugal) and Xunta de Galicia under programme 08MDS034 314PR. The authors are grateful to University of Vigo for financial support of the research of Emilio Rosales under a mobility grant.

\section{References}

[1] S. Hammami, A. Ouejhani, N. Bellakhal, M. Dachraoui, Application of Doehlert matrix to determine the optimal conditions of electrochemical treatment of tannery effluents, J. Hazard. Mater. 163 (2009) 251-258.

[2] J. Easton, The dye maker's view: in colour in dyehouse effluent, in: P. Cooper (Ed.), Society of Dyers and Colourists, Bradford, UK, 1995, p. 11.

[3] I.M. Banat, P. Nigam, D. Singh, R. Marchant, Microbial decolorization of textiledye-containing effluents: a review, Bioresour. Technol. 58 (1996) 217-227.

[4] V. Vimonses, S. Lei, B. Jin, C.W.K. Chow, C. Saint, Adsorption of congo red by three Australian kaolins, Appl. Clay Sci. 43 (2009) 465-472.

[5] D.J. Jefferies, P. Firestone, Chemical analysis of some coarse fish from a Suffolk river carried out as part of the preparation for the first release of captive-bred otters, J. Otter Trust. 1 (1984) 17-22.

[6] N. Tewari, P. Vasudevan, B.K. Guha, Study on biosorption of $\mathrm{Cr}(\mathrm{VI})$ by Mucor hiemalis, Biochem. Eng. J. 23 (2005) 185-192.

[7] G. Crini, Non-conventional low-cost adsorbents for dye removal: a review, Bioresour. Technol. 97 (2006) 1061-1085. 
[8] M. Vaca Mier, R. Lopez Callejas, R. Gehr, B.E. Jimenez Cisneros, P.J.J. Alvarez, Heavy metal removal with Mexican clinoptilolite: multi-component ionic exchange, Water Res. 35 (2001) 373-378.

[9] H. Figueiredo, M.M.M. Raposo, A.M. Fonseca, I.C. Neves, C. Quintelas, T. Tavares, Encapsulated pyridazine $\mathrm{Cr}$ (III) complexes prepared from biosorbents supported in zeolites, Stud. Surf. Sci. Catal. 158 B (2005) 1073-1080.

[10] H. Figueiredo, I.C. Neves, C. Quintelas, T. Tavares, M. Taralunga, J. Mijoin, P. Magnoux, Oxidation catalysts prepared from biosorbents supported on zeolites, Appl. Catal., B 66 (2006) 274-280.

[11] B. Silva, H. Figueiredo, C. Quintelas, I.C. Neves, T. Tavares, Zeolites as supports for the biorecovery of hexavalent and trivalent chromium, Microporous Mesoporous Mater. 116 (2008) 555-560.

[12] C. Quintelas, T. Tavares, Removal of chromium(VI) and cadmium(II) from aqueous solution by a bacterial biofilm supported on granular activated carbon, Biotechnol. Lett. 23 (2001) 1349-1353.

[13] C. Quintelas, T. Tavares, Lead (II) and Iron (II) removal from aqueous solution: biosorption by a bacterial biofilm supported on granular activated carbon, Resour. Environ. Biotechnol. 3 (2002) 193-202.

[14] T. Perraki, G. Kakali, F. Kontoleon, The effect of natural zeolites on the early hydration of Portland cement, Microporous Mesoporous Mater. 61 (2003) 205-212.

[15] APHA-AWWA-WPCF, Standard methods for the examination of water and wastewater, American Public Health Association (APHA), Washington, 1995.

[16] M. Qiu, C. Qian, J. Xu, J. Wu, G. Wang, Studies on the adsorption of dyes into clinoptilolite, Desalination 243 (2009) 286-292.

[17] V. Vimonses, S. Lei, B. Jin, C.W.K. Chow, C. Saint, Kinetic study and equilibrium isotherm analysis of Congo Red adsorption by clay materials, Chem. Eng. J. 148 (2009) 354-364.

[18] Y. Yao, F. Xu, M. Chen, Z. Xu, Z. Zhu, Adsorption behavior of methylene blue on carbon nanotubes, Bioresour. Technol. 101 (2010) 3040-3046.

[19] M. Do an, M. Alkan, Y. Onganer, Adsorption of methylene blue from aqueous solution onto perlite, Water Air Soil Pollut. 120 (2000) 229-248.

[20] D. Kratochvil, B. Volesky, Advances in the biosorption of heavy metals, Trends Biotechnol. 16 (1998) 291-300.

[21] T.W. Weber, R.K. Chakraborty, Pore and solid diffusion models for fixed bed adsorbents, J. Am. Inst. Chem. Eng. 20 (1974) 228-238.
[22] Y.S. Ho, J.F. Porter, G. McKay, Equilibrium isotherm studies for the sorption of divalent metal ions onto peat: copper, nickel and lead single component systems, Water Air Soil Pollut. 141 (2002) 1-33.

[23] K. Vijayaraghavan, Y. Yun, Bacterial biosorbents and biosorption, Biotechnol. Adv 26 (2008) 266-291.

[24] O. Redlich, D.L. Peterson, A useful adsorption isotherm, J. Phys. Chem. 63 (1959) 1024

[25] R. Sips, On the structure of a catalyst surface, J. Chem. Phys. 16 (1948) 490-495

[26] R.E. Treybal, Mass Transfer Operations, McGraw Hill, New York, 1968.

[27] Y.S. Ho, G. McKay, Pseudo-second order model for sorption processes, Process. Biochem. 34 (1999) 451-465.

[28] A.S. Özcan, B. Erdem, A. Özcan, Adsorption of Acid Blue 193 from aqueous solutions onto BTMA-bentonite, Colloids Surf., A 266 (2005) 73-81.

[29] S. Lagergren, Zur theorie der sogenannten adsorption gelöster stoffe, K. Sven. Vetenskapsakad. Handl. 24 (1898) 1-39.

[30] W.J. Weber, J.C. Morris, Kinetics of adsorption on carbon solution, J. Sanit. Eng. Div. Am. Soc. Civ. Eng. (1963) 354-364.

[31] E. Lorenc-Grabowska, G. Gryglewicz, Adsorption characteristics of Congo Red on coal-based mesoporous activated carbon, Dyes Pigm. 74 (2007) 34-40.

[32] H. Figueiredo, B. Silva, C. Quintelas, I.C. Neves, T. Tavares, Effect of the supporting zeolite structure on $\mathrm{Cr}$ biosorption: performance of a single-step reactor and of a sequential batch reactor-A comparison study, Chem. Eng. J. 163 (2010) 22-27.

[33] N. Nunes, R. Amaro, F. Costa, E. Rombi, M.A. Carvalho, I.C. Neves, A.M. Fonseca, Copper(II)-purine complexes encapsulated in NaY zeolite, Eur. J. Inorg. Chem. (2007) 1682-1689.

[34] E.M.N. Chirwa, Y. Wang, Hexavalent chromium reduction by Bacillus sp. in a packed-bed bioreactor, Environ. Sci. Technol. 31 (1997) 1446-1451.

[35] B.B. Nepple, J. Kessi, R. Bachofen, Chromate reduction by Rhodobacter sphaeroides, J. Ind. Microbiol. Biotechnol. 25 (2000) 198-203.

[36] T. Srinath, T. Verma, P.W. Ramteke, S.K. Garg, Chromium (VI) biosorption and bioaccumulation by chromate resistant bacteria, Chemosphere 48 (2002) 427-435.

[37] B. Silva, H. Figueiredo, I.C. Neves, T. Tavares, The role of pH on $\mathrm{Cr}(\mathrm{VI})$ Reduction and Removal by Arthrobacter viscosus, 2008, pp. 59-62.

[38] V. Vimonses, B. Jin, C.W.K. Chow, C. Saint, Enhancing removal efficiency of anionic dye by combination and calcination of clay materials and calcium hydroxide, J. Hazard. Mater. 171 (2009) 941-947. 